\title{
Agenesia renal y ectopia pélvica contralateral en varón infértil
}

A. de Pablo Cárdenas, M.A. Pinós Paul, J.I. Jiménez Aristu, F. Lozano Uruñuela, J.I. Villanueva Pérez, A.M. Santiago González de Garibay

Servicio de Urología. Hospital Virgen del Camino. Pamplona. Navarra.

Actas Urol Esp 2005; 29 (5): 534

$\mathrm{V}$

arón de 24 años. Estudiado por infertilidad primaria se diagnostica de azoospermia por agenesia bilateral de conductos deferentes.

La placa de la urografía intravenosa demuestra una ectopia renal pelviana derecha y una agenesia renal contralateral.

En caso de agenesia deferencial es preciso realizar una prueba de imagen que pondrá de manifiesto la existencia de posibles anomalías del tramo urinario, la prueba del sudor que descartará fibrosis quística y hay que tener en cuenta también la posibilidad de otras malformaciones congénitas extragenitourinarias (cardiovasculares, digestivas...).

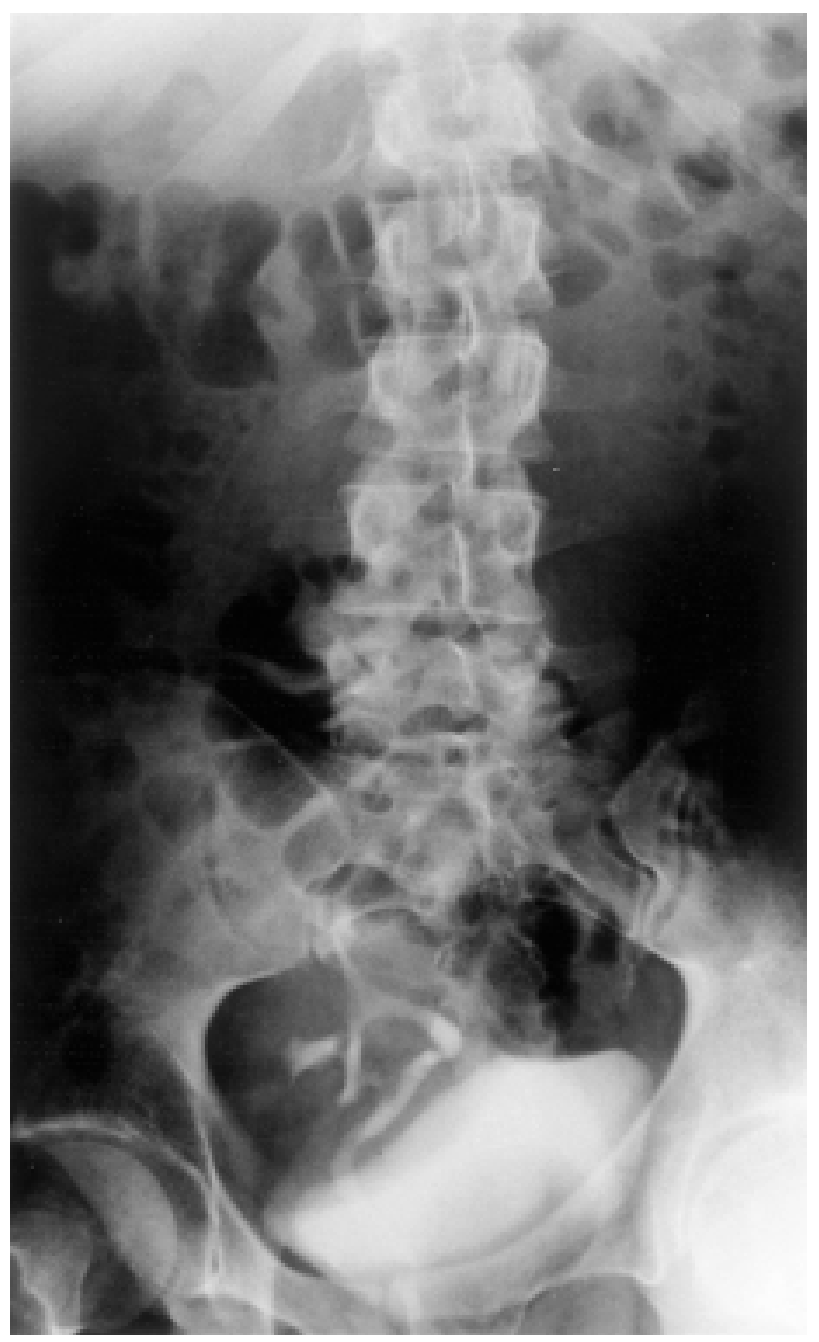

